\title{
Defining work stress in young workers
}

\begin{abstract}
Our study aims to answer the question "How do young workers perceive and respond to workrelated stressors?” For the purpose of this study, we define young workers as who are aged between 15 and 29 years, according to European Union. By interviewing 18 key participants, we found that young workers view job stress in three dimensions: a lack of opportunity to learn, poor social interaction, and lacking the opportunity to exercise initiative. Further, we found that young workers view their work demands as challenging tasks and they become job crafters to find more satisfaction in routine tasks.
\end{abstract}

Keyword: young workers; psychological wellbeing; work stress; generations; interview study 


\section{Introduction}

Young workers are classified broadly by the European Union (EU) as being those who are aged between 15 and 29 years. Overall, 4.2 million employees are classified as young workers in Australia. This group represents the current entrants into the Australian workforce and is vast in size, representing 21\% of the Australian population (Australian Bureau of Statistics, 2011). The size of the young generation workforce, coupled with the fact that the Baby Boomers are beginning to retire, makes a focus on the younger generation paramount. Indeed, understanding work-related issues from the perspective of the younger generation and adapting our management accordingly represents a real challenge in Australia and across the international community.

One crucial work-related issue that emanates from the literature is related to stress and coping among this younger generation. Research has found the young generation demographic to be more vulnerable to stress than older generations (APS, 2012). There are numerous empirical studies examining work stress among working adult populations (e.g. Newton \& Jimmieson, 2008; S. Sawang et al., 2010; S. Sawang, Oei, \& Goh, 2006); however, research focussing on young workers explicitly is scarce. Youth employment literature has tended to focus on the impact of training, work ethic and wages on labour market opportunities (see Bessant, 1996). Even though these foci are important they lead to a lack of research into the experience of young workers. Given the rapidly changing nature of the labour market and employment in Australia over the last decade there is a need to pay more attention to early work experience and its consequences among young workers (Roan \& Diamond, 2003).

Our study aims to fill a gap in the current research by investigating work stress and coping among Australian young workers. Specifically, our research explores the question "How do young workers perceive and respond to work-related stressors?” Younger workers have been referred to as 'Generation Y', the 'Echo boomers', 'Nexters', and/or 'Millennials' whose age between 20 to early 30 years old (Barnard et al. 1998; Burke and Ng 2006; Zemke et al. 2000). For the purpose of 
this study, we define young workers as who are aged between 15 and 29 years, according to EU (which is similar to Gen Y cohort).

The remainder of this paper is organized as follows. First, we review characteristics of young workers as defined in the literature. We then discuss the stress related theories and methodological information. The next section then follows with findings and discussion.

\section{Characteristics of young workers}

Overall, young workers are perceived as technically literate, educated, and ethnically diverse generation (Eisner, 2005). In term of personality, this group is described as being positive, polite, curious, and energetic (Francis-Smith, 2004).It has also been suggested that young workers expect good pay and benefits, rapid advancement, work/life balance, interesting and challenging work, and making a contribution to society. This is especially the case for pay with a recent study identifying pay as the most important motivational factor for young workers (Ng, Schweitzer, \& Lyons, 2010).

Mortimer and colleagues described young workers to be the most adaptable individuals compared to older workers (1992). For example, young workers are happy to work simultaneously in different project teams, while synchronous work can be viewed as a workplace stressor for older generations (Paul, 2001). However, other characteristics of young workers such as impatience, scepticism and lack of life experience mean they are prone to experiencing greater degrees of psychological distress than other generations (Hewlett, Sherbin, \& Sumberg, 2009). As such, it is important to unpack what triggers young workers' psychological distress and how we can help them manage their stress effectively so that they become healthy human capital for our nation. Stressed young workers can perceive themself as having low work competence (Ainsworth, Blehar, Waters, \& Wall, 1978; Paulsson, Ivergård, \& Hunt, 2005) and, in turn, this inhibits their desire to work and leads them to become voluntarily unemployed (Theodossiou, 1998). Indeed, recent research and surveys have found evidence of dissatisfaction in some young workers. However, for a range of reasons, such as lack of experience, or lack of other options, young workers may remain in these 
jobs - working with negative attitudes, cynical hostility and a vulnerability to poor health and wellbeing (Andreassi, 2013; Jamner, Shapiro, Goldstein, \& Hug, 1991). Workers’ poor health and wellbeing present a significant cost to employers as a result of absenteeism, reduced productivity while at work, providing cover for absent staff, the impact on the productivity and morale of peers, and voluntary turnover (OECD, 2011). A research focus on younger workers will fill a broad research gap in the stress literature and assist employers to attract and retain healthy young people in the workforce.

\section{Exposure vs. generation stress models}

Research shows that employed young people have relatively higher levels of wellbeing when compared with unemployed youth (O'Brien \& Feather, 1990). Nonetheless, the psychological wellbeing of employed young people who are exposed to work stressors may be just as deleterious as that of unemployment youth. Stress literatures have described the effects of stress on various health-related outcomes such as emotional strain and depression. The term 'stress exposure' is used when individuals exposed to stressful events are then at risk of negative psychological health (Coyle \& Vera, 2013). This risk may directly affect psychological wellbeing or may be mediated or moderated by other factors. Such factors include: coping styles (Goh, Sawang, \& Oei, 2010); selfefficacy or self-competence (DeNeve \& Cooper, 1998); and social support (Sukanlaya Sawang, 2012) to name just a few. However, an alternative model of stress generation postulates poor psychological wellbeing may cause individuals to precipitate stress, suggesting that the stress-strain process is fluid and serves as both an aetiology and consequence (Rudolph et al., 2000). Our current study employs the stress exposure framework to examine how young workers perceive and respond to work-related stress.

Drawing from classic theory of stress (Lazarus \& Folkman, 1984), a potentially stressful event will trigger the primary appraisal process which involves an assessment of the importance of a transaction for one's well-being. Three stress appraisals are challenge, harm/loss, and threat. 
When individuals perceive a stressor as a challenge, they view that stressor as an opportunity for growth and gain, which leads to employee motivation, satisfaction, and performance (LePine et al., 2005; Podsakoff et al., 2007). On the other hand, when individuals perceive a stressor as harm or threat, they think of a stressor as an obstacle or barrier to task accomplishment and personal growth (LePine, Podsakoff, \& LePine, 2005; Podsakoff, LePine, \& LePine, 2007). These cognitive evaluations are important to understand and reframe as early career experiences for young workers precede positive or negative attitudes and experiences in later stage of careers (Jamner et al., 1991).

Overall, this study sought to contribute to existing literature on the impact of the environmental context on young people’s psychological wellbeing. To date, research on young worker's experience of stress has focused on the relationship between employment, unemployment and subjective well-being among young people (see McKee-Ryan, Song, Wanberg, \& Kinicki, 2005 for a full review). This study adopts an alternate critical lens to explore how work stressors described among young workers. Indeed, it is necessary to understand the actual stressors in order to develop appropriate policies to assist young workers to minimise stress and optimise their productivity and performance.

\section{Method}

We adopted the relativist approach because we believe that information we obtained is valid only when it is relative to some particular frame of reference (Healy \& Perry, 2000). Phenomenological interviews are used to obtain a deeper understanding of the participants' experiences (Osborne, 1994). This interviewing method is open-ended, allowing the individual's experience to present itself as spontaneously as possible.

In approaching this research we were aware that our experiences and expectations could influence our interpretation of the information. We were aware that our views toward young workers were clouded by literatures we read and some perceptions of personalities and behaviors of young workers were formed prior to the interview. We were mindful of this potential bias, thus we used phonological interview approach, focusing on how phenomena are presented in different ways 
to individuals. Work stressors can be experienced in many ways from different perspectives, by one person or by many people. For example, job complexity can be experienced by one person as something challenge or threat. We asked broad and open ended questions so that the participants had sufficient opportunity to express their view point extensively (Bevan, 2014; Giorgi, 1997). Further, we provided an opportunity for participants to check the accuracy of the data. They were asked to read any transcripts of dialogues in which they have participated, consider that their words match what they actually intended. Further, we employed multiple coding approach, involving the data has been coded by four researchers, the cross checking of coding strategies and interpretation of data by additional two independent researchers (apart from authors). The total of four experienced researchers who independently coded the transcript showed substantial agreement.

\section{Participants}

We interviewed 18 key participants, who are Caucasian Australian and age between 17-29 years old (average age is 23 years). The participants were recruited through a snowball sampling. Of these, there were 13 female respondents and five male respondents (Table 1). Job tenure ranged between one month and six years (average tenure is 2.6 years). Seven key informants were schoolto-work transition and 11 informants were graduated worker (school-to-further education and work transition). The key informants were recruited through local advertisements and snowballing technique.

Insert Table 1 about here

A single in-depth semi-structured interview was employed and written consent to participate was obtained from each respondent. All participants were informed that they could refuse to answer certain questions or to withdraw from the research at any time. Interview questions included participants’ experiences in their current and past workplaces. Rather than adopting a rigid interview protocol, the interviewer took a flexible approach that allowed participants to bring 
up topics that were important to them. With participant consent, each interview was audio-taped and transcribed verbatim by a research assistant. Pseudonyms were assigned to all participants to assure confidentiality.

We follow the multi-stage content analysis suggested by Berelson, 1952 and Holsti, 1969. The transcripts were checked for accuracy. The transcripts were read several times to capture the main ideas from each participant's narrative. These perusals included a line-by-line review to identify units of meaning and recurrent themes. As the text was categorised, themes emerged, and these themes were labelled in ways that conformed to the study objectives. The analyses and categorisations were performed recursively, and the themes were sometimes revised to incorporate additional information.

\section{Findings}

Young workers are perceived to have high expectations and over-confidence (Martin, 2005) and often they overestimate their work skills and abilities (Egeler, 2003). Yet this claim can be questioned as past studies often described younger workers' work characteristics in terms of older generations. Our findings thus allowed young workers to reflect on themselves in relation to their work context. Key emerging themes (Table 2) describing work related stress and their views are described as follow.

Insert Table 2 about here

\section{They never let me shine and kept preaching at me!}

Young workers are perceived to be very proactive and prefer participative decision making (Loughlin \& Barling, 2001). Further, past studies defined work values among young workers as freedom and learning opportunities (Cennamo and Gardner 2008; Smola and Sutton 2002). Our interviews illustrated that young workers realised that they were on a learning curve in the workplace. However, young people believed that they were not incompetent and had better ideas 
on how to do things better. Occupational stress literature highlights the importance of job autonomy—a degree to which employees can decide how their work should be done (Daniels \& Guppy, 1994). Past research demonstrated that a lack of job autonomy engendered a depersonalised attitude among employees (Cordes \& Dougherty, 1993). Our interviews illustrated that young workers found that older workers tended not to agree with their ideas and always adhered to traditional ways. Young workers felt that their opinions had not been heard or had been ignored and this made them frustrated.

...Sometimes they (older colleague) tend to be a little bit not as willing to accept new ideas new ways of doing things sort of stuff whereas we (younger workers) can ... the older workers can be just set in their ways and resistant to change ...(Y03)

\section{Interpersonal conflict: generation crash}

Interpersonal conflict can be considered a salient work stressor among young workers because the development of interpersonal competencies occurs during middle (16 to 18 years old) to late (19 to 21 years old) adolescence. Generation Y has grown up in a world of opportunities and has been told 'you can do anything'(Twenge \& Campbell, 2008, p. 867). As a result, young workers are highly confident in themselves. While self-esteem can be a good personality trait, it can be a mixed blessing. For example, an experimental study illustrated that high self-esteem, comparing to low self-esteem, college students were less likeable and less friendly after they were criticised (Twenge \& Campbell, 2008). Therefore, young workers may react more defensively to feedback or comment from older colleagues. This perception can lead to interpersonal conflict as a source of stress. Our interview demonstrated that young workers felt that they have been treated as children by their older colleagues.

... She (older colleague) constantly corrects everyone on their language and, and has a very strict way of how the world should be and she's very entitled and she comes in 'ooh I'm only living on two and a half grand a month' and all this sort of bullshit... (Y04)

\section{Gen Y are job crafters to overcome routine tasks}


Job crafting is a psychological, social and physical act geared toward shaping a job task’s boundaries (Berg, Dutton, \& Wrzesniewski, 2008). Shaping means individuals change their way of thinking about the relationships between job tasks by changing the interactions and relationships they have with others at work. Traditional job design theories such as job characteristics model (Hackman \& Oldham, 1980), socio-technical systems theory (Pasmore, Francis, Haldeman, \& Shani, 1982), and the interdisciplinary work design framework (Campion \& McClelland, 1991) focus on the top-down approach; however, this approach may not fully reflect the impact of the Millennials’ work contexts (Grant \& Parker, 2009; Parker, Wall, \& Cordery, 2001). We found that young workers demonstrated an ability to craft their routine jobs in ways that would foster their own job satisfaction. For example, a clothing store retailer described how her role was to stand at the check-out counter within her section. At first it was a very boring task. She found a way to shape her job by being proactive and engaging with customers on the floor.

... When we get new stock in, we have to organise the area and when the sale finished, I was the one who went and organised it so that all of the new stock was at the front, and all the sale stock was together and all the brands were together and it was merchandised properly, and no one asked me to do it ... I feel happy and enthusiastic, and I feel like I want to do the best that I can ... (Y14)

This was similar to another young worker who modified his work situation by creating social interaction in his workplace.

... I'm not happy with the bosses but I'm enjoying my work. Different atmospheres, different people, you know talking to the truck drivers. Have a good chat or joke ... (Y17)

The above examples illustrate that young workers crafted their job by: (a) changing the job boundaries by taking on more (or fewer) tasks or changing ways to do tasks; (b) changing ways to interact with people; and (c) shaping their perceptions toward their jobs. Gen Y workers are perceived as flexible and creative workers but they are more likely to be bored at work 
(Broadbridge, Maxwell, \& Ogden, 2007). Through job crafting, young workers finds way to enjoy their work without formally redesigning the work structure or the organisation.

\section{Gen Y perceive stress in positive ways}

The experience of stress at work results in a range of dysfunctional psychological responses, such as anxiety, depression and burnout. In addition to the negative effects on physiological and psychological health, occupational stressors influence employee attitudes, including reduced job satisfaction and organisational commitment, as well as employee behaviours such as absenteeism and job performance deficits (Cooper, Dewe, \& O’Driscoll, 2001; O'Driscoll \& Cooper, 1994; S. Sawang et al., 2006). Job demands have been described as a hindrance stressor that cause negative outcomes as described prior (Demerouti, Bakker, Nachreiner, \& Schaufeli, 2001; Karasek, 1979). In contrast, we found young workers viewed their work demands as challenging tasks.

... I fit women that have had cancer of the breast, so they have had their breast removed, so when they first come into me, we literally are the first person they see after they have come out of hospital. So you feel shocked and overwhelmed first but then feel very committed, engaged because you know all your experience in 'how to handle someone who is very fragile' does become a great commitment because you want to provide top quality service and want to help them ... (Y05)

Young workers viewed work demands as their stressors that have the potential to promote mastery, personal growth, or future gains; as a result, they triggered positive emotions such as enthusiasm, commitment or active problem-solving (Cavanaugh, Boswell, Roehling, \& Boudreau, 2000). We found that young workers felt highly confident (which has been described as one of the unique characteristics of Gen Y, i.e., high levels of self-efficacy (Hewlett et al., 2009)) that they could fulfil their personal achievement by working hard.

\section{Managing young workers: Implications}

The workplace stress paradigm supports the negative relationship between perceived stress and individual wellbeing. However, past relevant literature tends to explore a narrow representation of 
work stressors (i.e., most research was on workload, work control and work security (Frone, 2003). Our findings extend the past research of young workers' stress.

Previous research views part-time work as an unwilling choice forced on young workers because of their age and experience (Walsh, 1999). Non-standard work leads to job security issues among workers (Mills, 2004). However, previous literature argues that part-time workers do not want job security because these workers do not plan on staying with the same employer for any prolonged period of time (Kalleberg, 2000). We found that the non- standard jobs have become a choice among young people, due to their lifestyles and work attitudes (Loughlin \& Barling, 2001). In the high technology sector, young workers voluntarily choose temporary assignments for fear of the 'mindless repetition' of full-time work (Lessard \& Baldwin, 2000). In other word, young people want flexible jobs that match their lifestyle (Mills, 2004).

Young workers view job stress in three dimensions: a lack of opportunities to learn, poor social interaction and lacking opportunities to exercise initiative (autonomy). Workplace conflicts are the most frequently cited sources of work-related stress, and young workers frequently reported this type of stressor more than older workers (Harvey, Blouin, \& Stout, 2006). Young workers are considered proactive, actively pursuing changes that are favourable to self-development (Loughlin \& Barling, 2001). However, conflict may pose a particular problem to proactive types because of their more goal-directed and steadfast attempts to resolve issues in their environment, and anyone interrupting this may be a source of frustration leading to stress (Crant, 2000). Our findings illustrate the interpersonal conflict or poor interaction between young and older generations. This type of negative interpersonal interaction has become a work-related stressor. Past research also found that young individuals often used a high percentage of passive-indirect strategies (Bergstrom \& Nussbaum, 1996), for example, when one acts aggressively concerning one’s self-interest, but is passive or unconcerned about the conflicted other's needs.

Social interaction or workplace relationships have become critical stressors among young workers. Today, we tend to have an intergenerational mix in the workplace. Older workers think 
that Gen Y workers expect too much and they do not want anyone to tell them what to do (Smola \& Sutton, 2002). On the other hand, Gen Y workers see older workers as overcautious and hierarchy worshipping, overly influenced by their parents’ Depression mentality (Jurkiewicz, 2000). Young workers who define workplace interaction as one dimension of job quality are more likely to have their psychological wellbeing impacted upon due to generational conflict. Today’s organisation needs to mitigate the impact of this conflict by establishing a collaborative intergenerational workforce. To encourage organisational members bridging this gap, organisations should create an atmosphere of fellowship where people can learn from and with each other. Managers should encourage younger workers' ability to drive, change, and challenge the status quo. Given their need for autonomy and flexibility, young workers will work with negative feeling under rigid structures and inflexible management styles.

Communication researchers assume that conflict is a normal part of everyday interaction (Bergstrom \& Nussbaum, 1996). Therefore, conflict will emerge within the relation between younger and older workers. Due to a lack of their life experience, we cannot expect young workers to have more mature and reasonable ways of dealing with the conflict. When an interpersonal conflict arises, young workers may become confrontational over the issue while older workers remain solution-oriented. A pragmatic implication of our findings is to make employees aware that they may have differing preferences in dealing with a conflict that may, to some extent, explain problems in their intergenerational communication. Workplace training can increase the awareness of generations, and reduce the negative outcome of conflict which then mitigates the negative wellbeing among employees.

Previous research shows that young workers are highly motivated (e.g. Smola \& Sutton, 2002; Twenge \& Campbell, 2008; Wyn \& Woodman, 2006). Thus, it is important to provide these young workers with opportunities for challenging work and growth. To attract and retain young workers, organisations should find strategic human resource policies that meet young workers' 
desired job characteristics in such a way that work stress is minimised and job satisfaction and performance are maximised.

\section{Limitations and Recommendations for Future Research}

The results of this study are limited in terms of transferability. Since the findings of study are specific to a small number of participants, it is impossible to demonstrate that the findings and conclusions are applicable to a wider population. However, each participant may be unique, and represent an example within a broader group (young workers). As a result, the prospect of transferability should not be immediately rejected (Denscombe, 1998). To increase transferability, larger sample should be sought, and a triangulation the findings with positivistic approach (statistical analysis) is recommended. Second, the narrative description of the participants which were provided in our study, does not cover the full information of the economic, social, and psychological qualities of the participants. Therefore, the interpretation of our findings should be considered a preliminary. The future study can perhaps include a full description of all the contextual factors impinging on the inquiry.

\section{References}

Ainsworth, M. D. S., Blehar, M. C., Waters, E., \& Wall, S. (1978). Patterns of attachment: A psychological study of the strange situation. Hillsdale, NJ: Erlbaum.

Andreassi, J. L. (2013). Psychophysiology: Human behavior \& physiological response. East Sussex, U.K.: Psychology Press.

APS. (2012). Stress and wellbeing in Australia in 2011: A state of the nation survey. Melbourne: The Australian Psychological Society Australian Bureau of Statistics. (2011). Household Use of Information Technology. (8146.0). Canberra: Australian Bureau of Statistics. 
Berg, J. M., Dutton, J. E., \& Wrzesniewski, A. (2008). What is job crafting and why does it matter. Theory-to-practice briefing, Ross School of Business, University of Michigan. Accessed on August, 24, 2008.

Bergstrom, M. J., \& Nussbaum, J. F. (1996). Cohort Difference in Interpersonal Conflict: Implications for the Older Patient-Younger Care Provider Interaction. Health Communication, 8(3), 233-248. doi: 10.1207/s15327027hc0803_4

Bessant, J. (1996). Adolescents as offenders, social order, and the morality of work in a postindustrial society: The Australian experience. Journal of Criminal Justice, 24(6), 523535. doi: 10.1016/S0047-2352(96)00037-2

Bevan, M. T. (2014). A method of phenomenological interviewing. Qualitative health research, 24(1), 136-144. doi: 10.1177/1049732313519710

Broadbridge, A. M., Maxwell, G. A., \& Ogden, S. M. (2007). Experiences, perceptions and expectations of retail employment for Generation Y. Career Development International, 12(6), 523-544. doi: 10.1108/13620430710822001

Campion, M. A., \& McClelland, C. L. (1991). Interdisciplinary examination of the costs and benefits of enlarged jobs: A job design quasi-experiment. Journal of Applied Psychology, 76(2), 186-198. doi: 10.1111/j.1744-6570.1990.tb02395.x

Cavanaugh, M. A., Boswell, W. R., Roehling, M. V., \& Boudreau, J. W. (2000). An empirical examination of self-reported work stress among US managers. Journal of Applied Psychology, 85(1), 65-74. doi: 10.1037//0021-9010.85.1.65

Cooper, C. L., Dewe, P. J., \& O’Driscoll, M. P. (2001). Organizational stress: A review and critique of theory, research, and applications. Thousand Oaks, CA: Sage.

Cordes, C. L., \& Dougherty, T. W. (1993). A review and an integration of research on job burnout. Academy of Management Review, 18(4), 621-656. doi: 10.5465/AMR.1993.9402210153 
Coyle, L. D., \& Vera, E. M. (2013). Uncontrollable stress, coping, and subjective well-being in urban adolescents. Journal of youth studies(ahead-of-print), 1-13. doi: 10.1080/13676261.2012.756975

Crant, J. M. (2000). Proactive Behavior in Organizations. Journal of Management, 26(3), 435-462. doi: $10.1177 / 014920630002600304$

Daniels, K., \& Guppy, A. (1994). Occupational stress, social support, job control, and psychological well-being. Human Relations, 47(12), 1523-1544. doi: 10.1177/001872679404701205

Demerouti, E., Bakker, A. B., Nachreiner, F., \& Schaufeli, W. B. (2001). The job demandsresources model of burnout. Journal of Applied Psychology, 86(3), 499-512. doi: 10.1037/0021-9010.86.3.499

DeNeve, K. M., \& Cooper, H. (1998). The happy personality: a meta-analysis of 137 personality traits and subjective well-being. Psychological bulletin, 124(2), 197-229. doi: 0.1037/00332909.124.2.197

Denscombe, M. (1998). The good research guide for small-scale social research projects. Buckingham, U.K.: Open University Press

Egeler, D. (2003). Shaping the next generation. Colorado Springs, CO: Navpress.

Eisner, S. P. (2005). Managing generation Y. SAM Advanced Management Journal, 70(4), 4-15.

Francis-Smith, J. (2004). Surviving and thriving in the multigenerational workplace. Retrieved 9 December 2015, from Journal Record http://journalrecord.com/2004/08/26/surviving-andthriving-in-the-multigenerational-workplace/

Frone, M. R. (2003). Predictors of overall and on-the-job substance use among young workers. Journal of Occupational Health Psychology, 8(1), 39-54. doi: 10.1037/1076-8998.8.1.39

Giorgi, A. (1997). The theory, practice, and evaluation of the phenomenological method as a qualitative research procedure. Journal of phenomenological psychology, 28(2), 235-260. doi: 10.1163/156916297X00103 
Goh, Y. W., Sawang, S., \& Oei, T. P. S. (2010). The Revised Transactional Model (RTM) of occupational stress and coping: an improved process approach. Australian and New Zealand Journal of Organisational Psychology, 3(1), 13-20. doi: 10.1375/ajop.3.1.13

Grant, A. M., \& Parker, S. K. (2009). 7 Redesigning Work Design Theories: The Rise of Relational and Proactive Perspectives. The Academy of Management Annals, 3(1), 317-375. doi: $10.1080 / 19416520903$

Hackman, J. R., \& Oldham, G. R. (1980). Work redesign. Reading, MA: Addison-Wesley

Harvey, S., Blouin, C., \& Stout, D. (2006). Proactive personality as a moderator of outcomes for young workers experiencing conflict at work. Personality and Individual differences, 40(5), 1063-1074. doi: 10.1016/j.paid.2005.09.021

Healy, M., \& Perry, C. (2000). Comprehensive criteria to judge validity and reliability of qualitative research within the realism paradigm. Qualitative market research: An international journal, 3(3), 118-126. doi: 10.1108/13522750010333861

Hewlett, S. A., Sherbin, L., \& Sumberg, K. (2009). How Gen Y \& Boomers will reshape your agenda. Harvard Business Review, 87(7/8), 71-76. doi: pubmed/19630257

Jamner, L. D., Shapiro, D., Goldstein, I. B., \& Hug, R. (1991). Ambulatory blood pressure and heart rate in paramedics: effects of cynical hostility and defensiveness. Psychosomatic Medicine, 53(4), 393-406. doi: 10.1097/00006842-199107000-00005

Jurkiewicz, C. L. (2000). Generation X and the public employee. Public Personnel Management, 29(1), 55-74. doi: 10.1177/009102600002900105

Kalleberg, A. L. (2000). Nonstandard employment relations: Part-time, temporary and contract work. Annual review of sociology, 26, 341-365. doi: 10.1146/annurev.soc.26.1.341

Karasek, R. A. (1979). Job demands, job decision latitude, and mental strain: Implications for job redesign. Administrative science quarterly, 24(2), 285-308. doi: 10.2307/2392498

Lessard, B., \& Baldwin, S. (2000). Netslaves: True tales of working the web. Toronto, Ontario: McGraw Hill. 
Loughlin, C., \& Barling, J. (2001). Young workers' work values, attitudes, and behaviours. Journal of Occupational and Organizational Psychology, 74(4), 543-558. doi:

10.1348/096317901167514

Martin, C. A. (2005). From high maintenance to high productivity: What managers need to know about Generation Y. Industrial and commercial training, 37(1), 39-44. doi:

$10.1108 / 00197850510699965$

McKee-Ryan, F., Song, Z., Wanberg, C. R., \& Kinicki, A. J. (2005). Psychological and physical well-being during unemployment: a meta-analytic study. Journal of Applied Psychology, 90(1), 53-76. doi: 10.1037/0021-9010.90.1.53

Mills, M. (2004). Demand for flexibility or generation of insecurity? The individualization of risk, irregular work shifts and Canadian youth. Journal of youth studies, 7(2), 115-139. doi: $10.1080 / 1367626042000238677$

Mortimer, J. T., Finch, M., Shanahan, M., \& Ryu, S. (1992). Work experience, mental health, and behavioral adjustment in adolescence. Journal of Research on Adolescence, 2(1), 25-57. doi: 10.1207/s15327795jra0201_2

Newton, C. J., \& Jimmieson, N. L. (2008). Role stressors, participative control, and subjective fit with organisational values: Main and moderating effects on employee outcomes. Journal of Management \& Organization, 14(1), 20-39. doi: 10.5172/jmo.2008.14.1.20

Ng, E. S., Schweitzer, L., \& Lyons, S. T. (2010). New generation, great expectations: A field study of the millennial generation. Journal of Business and Psychology, 25(2), 281-292. doi: 10.1007/s10869-010-9159-4

O'Brien, G. E., \& Feather, N. T. (1990). The relative effects of unemployment and quality of employment on the affect, work values and personal control of adolescents. Journal of Occupational Psychology, 63(2), 151-165. doi: 10.1111/j.2044-8325.1990.tb00517.x 
O'Driscoll, M. P., \& Cooper, C. L. (1994). Coping with work-related stress: A critique of existing measures and proposal for an alternative methodology. Journal of occupational and organizational psychology, 67(4), 343-354.

OECD. (2011). OECD Employment Outlook 2011. Pascal, Paris: OECD Publishing.

Osborne, J. W. (1994). Some similarities and differences among phenomenological and other methods of psychological qualitative research. Canadian Psychology/Psychologie Canadienne, 35(2), 167. doi: 10.1037/0708-5591.35.2.167

Parker, S. K., Wall, T. D., \& Cordery, J. L. (2001). Future work design research and practice: Towards an elaborated model of work design. Journal of Occupational and Organizational Psychology, 74(4), 413-440. doi: 10.1348/096317901167460

Pasmore, W., Francis, C., Haldeman, J., \& Shani, A. (1982). Sociotechnical systems: A North American reflection on empirical studies of the seventies. Human Relations, 35(12), 11791204. doi: $10.1177 / 001872678203501207$

Paul, P. (2001). Getting inside gen Y. American Demographics, 23(9), 42-49.

Paulsson, K., Ivergård, T., \& Hunt, B. (2005). Learning at work: competence development or competence-stress. Applied Ergonomics, 36(2), 135-144. doi: 10.1016/j.apergo.2004.09.008

Roan, A. M., \& Diamond, C. (2003). Starting out: the quality of working life of young workers in the retail and hospitality industries in Australia. International Journal of Employment Studies, 11(2), 91-119.

Rudolph, K. D., Hammen, C., Burge, D., Lindberg, N., Herzberg, D., \& Daley, S. E. (2000). Toward an interpersonal life-stress model of depression: The developmental context of stress generation. Development and Psychopathology, 12(2), 215-234. doi: http://hammenlab.psych.ucla.edu/pubs/00towardan.pdf

Sawang, S. (2012). Is there an inverted U-shaped relationship between job demands and work engagement: The moderating role of social support? International Journal of Manpower, 33(2), 178-186. doi: 10.1108/01437721211225426 
Sawang, S., Oei, T., Goh, Y. W., Wilman, M., Markhum, E., \& Ranawake, D. (2010). The Ways of Coping Checklist revision-Asian version (WCCL-ASIAN): a new factor structure with confirmatory factor analysis. Applied Psychology: An International Review, 59(2), 202-219. doi: $0.4038 /$ sljpsyc.v4i2.6314

Sawang, S., Oei, T. P. S., \& Goh, Y. W. (2006). Are country and culture values interchangeable? A case example using occupational stress and coping. International Journal of Cross Cultural Management, 6(2), 205-219. doi: 10.1177/1470595806066330

Smola, K. W., \& Sutton, C. D. (2002). Generational differences: Revisiting generational work values for the new millennium. Journal of organizational behavior, 23(4), 363-382. doi: 10.1002/job.147

Theodossiou, I. (1998). The effects of low-pay and unemployment on psychological well-being: A logistic regression approach. Journal of health economics, 17(1), 85-104. doi: 10.1016/S0167-6296(97)00018-0

Twenge, J. M., \& Campbell, S. M. (2008). Generational differences in psychological traits and their impact on the workplace. Journal of Managerial Psychology, 23(8), 862-877. doi: $10.1108 / 02683940810904367$

Walsh, J. (1999). Myths and counter-myths: an analysis of part-time female employees and their orientations to work and working hours. Work, Employment \& Society, 13(2), 179-203. doi: $10.1177 / 09500179922117908$

Wyn, J., \& Woodman, D. (2006). Generation, youth and social change in Australia. Journal of youth studies, 9(5), 495-514. doi: 10.1080/13676260600805713 
Table 1: Demographic information of the respondents.

\begin{tabular}{|c|c|c|c|c|c|c|c|}
\hline ID & Age & Gender & Industry & Tenure & Position & Work status & Education \\
\hline Y01 & 27 & $\mathrm{f}$ & Health & 5 & Receivable Assistant & fulltime & Diploma \\
\hline Y02 & 28 & $\mathrm{f}$ & Health & 3.6 & Medical receptionist & fulltime & Bachelor \\
\hline Y03 & 21 & $\mathrm{f}$ & Social services & 1 & Counsellor & part-time & Bachelor \\
\hline Y04 & 25 & $\mathrm{~m}$ & Commercial Services & 0.4 & Stylist & part-time & High school \\
\hline Y05 & 19 & $\mathrm{f}$ & Government & 1.9 & Administrator & fulltime & Diploma \\
\hline Y06 & 22 & $\mathrm{f}$ & Commercial Services & 0.8 & Administrator & fulltime & Diploma \\
\hline Y07 & 29 & $\mathrm{f}$ & Social services & 0.1 & Support officer & fulltime & Diploma \\
\hline Y08 & 23 & $\mathrm{f}$ & Commercial Services & 6 & Telemarketer & part-time & Bachelor \\
\hline Y09 & 26 & $\mathrm{~m}$ & Manufacturing & 5 & Cabinet maker & fulltime & Diploma \\
\hline Y10 & 27 & $\mathrm{f}$ & Government & 0.4 & investigator & fulltime & Master \\
\hline Y11 & 25 & $\mathrm{~m}$ & Wholesales \& Retails & 3.5 & Supervisor & part-time & Bachelor \\
\hline Y12 & 17 & $\mathrm{f}$ & Wholesales \& Retails & 1.1 & Sale assistant & Causal & High school \\
\hline Y13 & 26 & $\mathrm{~m}$ & Wholesales \& Retails & 6 & Service assistant & fulltime & High school \\
\hline Y14 & 19 & $\mathrm{f}$ & Wholesales \& Retails & 0.5 & Sale assistant & part-time & High school \\
\hline Y15 & 19 & $\mathrm{f}$ & Wholesales \& Retails & 1.3 & Sale assistant & part-time & High school \\
\hline Y16 & 19 & $\mathrm{f}$ & Wholesales \& Retails & 4 & Supervisor & Causal & High school \\
\hline Y17 & 20 & $\mathrm{~m}$ & Wholesales \& Retails & 2.5 & Floor assistant & fulltime & High school \\
\hline Y18 & 24 & $\mathrm{f}$ & Wholesales \& Retails & 4.5 & Sales manager & fulltime & Bachelor \\
\hline
\end{tabular}


Table 2: A summary of emerging themes

\section{Emerging themes}

They never let me shine and kept preaching at me!

Interpersonal conflict: Generation crash

Gen Y are job crafters

Gen Y perceive stress in positive ways

\section{Descriptions}

A perception of lacing freedom and learning opportunity

A perception of being treated as a child

An ability to craft their routine jobs in ways that would foster their own job satisfaction

Job stressors are seen as their personal challenge. 